\title{
Cationic Pd(II) complexes acting as topoisomerase II inhibitors: Synthesis, characterization, DNA interaction and cytotoxicity
}

\author{
Fillipe V. Rocha ${ }^{\mathrm{a}, \mathrm{b}, *}$, Carolina V. Barra ${ }^{\mathrm{a}}$, Saulo S. Garrido ${ }^{\mathrm{c}}$, Francine A. Manente ${ }^{\mathrm{d}}$, Iracilda Z. Carlos ${ }^{\mathrm{d}}$, \\ Javier Ellena ${ }^{\mathrm{e}}$, Andrea S.C. Fuentes ${ }^{\mathrm{f}}$, Arnaud Gautier ${ }^{\mathrm{g}}$, Laurent Morel ${ }^{\mathrm{h}}$, Antonio E. Mauro ${ }^{\mathrm{a}}$, Adelino V.G. Netto ${ }^{\mathrm{a}}$ \\ a Departamento de Química Geral e Inorgânica, Instituto de Química, UNESP, CEP 14801-970 Araraquara, SP, Brazil \\ b Department of Chemistry, Federal University of São Carlos, São Carlos, SP CEP 13.565-905, Brazil \\ c Departamento de Bioquímica e Tecnologia Química, Instituto de Química, UNESP, CEP 14801-970 Araraquara, SP, Brazil \\ d Departamento de Análises Clínicas, Faculdade de Ciências Farmacêuticas de Araraquara, UNESP - Univ. Estadual Paulista, P. 0. Box 502, Araraquara, São Paulo 14801-902, Brazil \\ e Instituto de Física, Universidade de São Paulo, São Carlos 13560-970, SP, Brazil \\ ${ }^{\mathrm{f}}$ Laboratory of Molecular Biology, Department of Genetics and Evolution, Federal University of São Carlos, Rodovia Washington Luis Km 235, 13565-905 São Carlos, SP, Brazil \\ ' Clermont-Université, ICCF, Université Blaise Pascal, CNRS, UMR 6296, 63177 Aubière Cedex, France \\ ${ }^{\text {h } C l e r m o n t-U n i v e r s i t e ́, ~ U n i v e r s i t e ́ ~ B l a i s e ~ P a s c a l, ~ G r e D ~ U M R ~} 6247$ CNRS, INSERM U931, 24 Avenue des Landais, 63177 Aubière Cedex, France
}

Pd(II) 4-methyl-3-thiosemicarbazide complexes with interesting in vitro antitumor activity were synthesized. These compounds are unable to interact to the DNA in low concentration, but are capable of inhibiting human topoisomerase II $\alpha$ and cathepsin B in the same range of concentration.

Type II topoisomerases are a class of ubiquitous enzymes that alter DNA topology by catalyzing the passing of an intact DNA double helix through a transient double-stranded break made in a second helix [1]. The topoisomerase II $\alpha$ (topo II $\alpha$ ) isoform is considered to be the primary pharmacological target for some of the most active drugs currently available for the treatment of human malignancies, since topo II $\alpha$ is highly up-regulated in transformed and cancer cells [2-5]. All topoisomerase II-targeting drugs are able to interfere with at least one step of the catalytic cycle [6]. Agents able to stabilize the covalent DNA topo II $\alpha$ complex are traditionally called topo II $\alpha$ poisons (e.g. doxorubicin, daunorubicin, mitoxantrone, amsacrine, and etoposide) whereas those acting on any of the other steps in the catalytic cycle are called catalytic inhibitors [6,7]. The cytotoxic effects of these agents may be mediated by the formation of an intermediate covalent DNA-topo II $\alpha$ complex, which is highly effective in triggering tumor cell apoptosis [8]. There is now a growing body of evidence to support that topo II $\alpha$ is highly sensitive to thiol-reactive agents such as quinones [9], selenium compounds [10], cadmium [11], thimerosal [12] and cisplatin [13]. According to Hasinoff and coworkers [13], topo II $\alpha$ monomer has at least five free cysteines that could potentially react with a thiophilic metal center. Given that the electrophilic reaction of soft metals with critical sulfhydryl groups on topo II $\alpha$ is thought, in part, to be responsible for its inhibition, this suggests that other metal based compounds

\footnotetext{
* Corresponding author at: Department of Chemistry, Federal University of São Carlos, São Carlos, SP CEP 13.565-905, Brazil

E-mail address: fillipe@ufscar.br (F.V. Rocha).
}

bearing thiophillic metal can be investigated as new potential inhibitor of topo II $\alpha$.

In this sense, palladium(II) derivatives soon appeared to be excellent candidates because of its high affinity for sulfur-containing ligands [14]. An important breakthrough reported by Caires' group has revealed that the cyclopalladated $\left[\mathrm{Pd}_{2}\left(\mathrm{~S}(-) \mathrm{C}_{2}, \mathrm{~N}-\mathrm{dmpa}\right)_{2}(\mu\right.$-dppe $\left.) \mathrm{Cl}_{2}\right]\{\mathrm{dmpa}=\mathrm{N}, \mathrm{N}-\mathrm{di}-$ methyl-1-phenethylamine; dppe $=1.2$-bis(diphenylphosphino)ethane interacts with protein thiol groups in the mitochondrial membrane [15, 16]. In addition, this class of compounds has also displayed the ability to inhibit cathepsin B [17], a cysteine protease whose active site is composed of cysteine, histidine, and asparagine residues in a catalytic triad [18]. It is believed that the Cys residue in the cathepsin B catalytic site might be able to bind to $\mathrm{Pd}(\mathrm{II})$ center replacing one of its ligands (e.g. $\mathrm{Cl}^{-}, \mathrm{H}_{2} \mathrm{O}$ ), while the remaining ligand moiety might establish favourable interactions with other residues in the active site cavity [19]. Surprisingly, very few studies on the topo II $\alpha$ inhibition activity of $\mathrm{Pd}(\mathrm{II})$ compounds have been described so far [20].

Recently, we have synthesized cationic complexes of the type $\left[\mathrm{PdX}(4-\mathrm{PhT})\left(\mathrm{PPh}_{3}\right)\right] \mathrm{X}\left(\mathrm{PPh}_{3}=\right.$ triphenylphosphine; 4-PhT = 4-phenyl-3-thiosemicarbazide; $\mathrm{X}=\mathrm{Cl}, \mathrm{Br}, \mathrm{I}, \mathrm{SCN}$ ) and evaluated their cytotoxic effects on breast (LM3) and lung (LP07) tumor murine cells [21]. These Pd(II) compounds were more cytotoxic towards LM3 cell line than cisplatin $(30.3 \pm 3.7 \mu \mathrm{M})$, displaying $\mathrm{IC}_{50}$ values in the range $2.79-8.84 \mu \mathrm{M}$. For the LP07 cells, most of these complexes exhibited cytotoxic effects similar to that of cisplatin $(4.3 \pm 0.4 \mu \mathrm{M})$.

Spectroscopic studies of model reactions with guanosine and agarose gel mobility shift assay showed that $\left[\mathrm{PdX}(4-\mathrm{PhT})\left(\mathrm{PPh}_{3}\right)\right] \mathrm{X}$ complexes have a limited reactivity towards nucleobases and DNA. We therefore hypothesized that one plausible molecular target for this type of complexes might be thiol-containing molecules, such as topo II $\alpha$ and cathepsin B. As a part of our continuing research into the coordination and biological chemistry of metal-based compounds [22-24], we present in this work the synthesis, characterization, DNA interaction 
<smiles>CNC(=S)NN</smiles><smiles>CNC1=[SH][P@](Cl)(P[PbH2])NN1</smiles>

$\underset{(\mathrm{X}=\mathrm{Br}, \mathrm{I}, \mathrm{SCN})}{\stackrel{\mathrm{MeOH} / \mathrm{H}_{2} \mathrm{O}(5: 1)}{\longrightarrow}}$

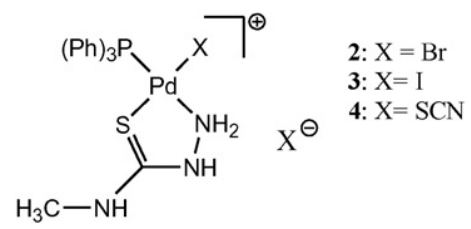

Scheme 1. Synthesis of complexes 1-4.

studies, in vitro cytotoxicity and inhibitory activity evaluation (topoisomerases I and II, cathepsin B) of four cationic compounds of the type $\left[\mathrm{PdX}\left(\mathrm{PPh}_{3}\right)(4-\mathrm{MeT})\right] \mathrm{X}\left\{\mathrm{PPh}_{3}=\right.$ triphenylphosphine; 4$\mathrm{MeT}=4$-methyl-3-thiosemicarbazide; $\mathrm{X}=\mathrm{Cl}(\mathbf{1}), \mathrm{Br}(\mathbf{2}), \mathrm{I}(\mathbf{3}), \mathrm{SCN}(\mathbf{4})$ \}.

The synthesis of the $\left[\mathrm{PdX}(4-\mathrm{MeT})\left(\mathrm{PPh}_{3}\right)\right] \mathrm{X}$ was achieved starting from bis(acetonitrile)dichloropalladium(II) (see synthetic procedures, ESI†). First, $\mathrm{PPh}_{3}$ and 4-methyl-3-thiosemicarbazide displace the labile ligand acetonitrile and one of the two chloro-ions to obtain $\mathbf{1}$. In a second step, the $\mathrm{Cl}$ ions are easily replaced by $\mathrm{Br}$, I and SCN ions by the addition of two equivalents of their appropriate potassium salt to afford 2 4 (Scheme 1).

The formation of the $\left[\mathrm{PdX}(4-\mathrm{MeT})\left(\mathrm{PPh}_{3}\right)\right] \mathrm{X}$ compounds was confirmed by elemental analysis, IR and ${ }^{1} \mathrm{H}$ NMR spectroscopies and ESI/ MS spectra (ESI $\dagger$ ). Formation of the $N, S$-chelated products was proved by spectroscopic data. IR spectra show a significant shift of $30 \mathrm{~cm}^{-1}$ to lower frequency for the $\nu \mathrm{C}=\mathrm{S}$ band after coordination. Variation of $\sim 4 \mathrm{ppm}$ downfield of the chemical shift $\left({ }^{1} \mathrm{H}\right.$ NMR) was observed for the two N2 protons after complexation. ESI/MS spectra confirmed the expected molecular mass of the compounds. After several attempts, single crystals suitable for X-ray diffraction studies were obtained for complexes 3 and 4 by vapor diffusion of diethyl ether at $4{ }^{\circ} \mathrm{C}$ into a saturated methanol. The ORTEP representations of cationic compounds $\mathbf{3}$ and $\mathbf{4}$ with the atom labeling scheme are presented in Fig. 1A and B, respectively.

Thiosemicarbazide acts as a neutral bidentate ligand leading to cis coordination through its S1 and N2 atoms to form a five membered ring. The remaining two coordination sites of the palladium atom are
Table 1

Cytotoxicity values for complexes 1-4.

\begin{tabular}{llll}
\hline \multirow{2}{*}{ Compound } & \multicolumn{2}{l}{$\mathrm{IC}_{50}(\mu \mathrm{M})$} & \\
\cline { 2 - 4 } & $\mathrm{LM3}$ & $\mathrm{LP07}$ & $\mathrm{MCF}-7$ \\
\hline$\left[\mathrm{PdCl}\left(\mathrm{PPh}_{3}\right)(4-\mathrm{MeT})\right] \mathrm{Cl}(\mathbf{1})$ & $5.92 \pm 0.59$ & $5.61 \pm 1.32$ & $8.78 \pm 1.12$ \\
{$\left[\mathrm{PdBr}\left(\mathrm{PPh}_{3}\right)(4-\mathrm{MeT})\right] \mathrm{Br}(\mathbf{2})$} & $6.05 \pm 0.76$ & $6.98 \pm 0.71$ & $9.04 \pm 1.27$ \\
{$\left[\mathrm{PdI}\left(\mathrm{PPh}_{3}\right)(4-\mathrm{MeT})\right] \mathrm{I}(\mathbf{3})$} & $3.22 \pm 0.84$ & $4.69 \pm 0.14$ & $9.54 \pm 1.01$ \\
{$\left[\mathrm{Pd}(\mathrm{SCN})\left(\mathrm{PPh}_{3}\right)(4-\mathrm{MeT})\right] \mathrm{SCN}(\mathbf{4})$} & $5.55 \pm 0.20$ & $4.83 \pm 0.91$ & $10.63 \pm 0.40$ \\
$4-\mathrm{MeT}$ & $>100$ & $>100$ & $>100$ \\
Cisplatin & $30.3 \pm 3.7$ & $4.3 \pm 0.4$ & $>50$ \\
Etoposide & nd & nd & $44.87 \pm 4.87$ \\
\hline
\end{tabular}

nd., not determined.

occupied by an iodide ion (3) or a thiocyanate group (4) coordinated trans to $\mathrm{S} 1$ and a triphenylphosphine ligand coordinated trans to N2. The palladium atom adopts a distorted square-planar geometry with bond lengths and angles in the usual range expected [25] [ESI†].

In vitro cytotoxic activity of ligand 4-MeT and complexes 1-4 was determined towards LM3 (murine mammary adenocarcinoma), LP07 (murine lung adenocarcinoma) and MCF-7 (human breast adenocarcinoma) cell lines by means of the colorimetric MTT assay. The corresponding $\mathrm{IC}_{50}$ values are listed in Table 1.

Our data for the LM3 cell line show that all the Pd(II) compounds are more cytotoxic than cisplatin, exhibiting $\mathrm{IC}_{50}$ values in the range 3.22-6.05 $\mu \mathrm{M}$. Complex 3 was ca. 9.5 times more active than the reference drug. The complexes 1-4 displayed remarkable cytotoxic levels over the 7.66-11.03 $\mu \mathrm{M}$ concentration range, being ca. 5-fold more potent than etoposide against MCF-7 tumor cells. Cisplatin showed no drug response at concentrations $<50 \mu \mathrm{M}$. Concerning the cytotoxic activity on LP07 cells, compounds $\mathbf{1 - 4}$ showed interesting cytotoxicity levels (4.69-6.98 $\mu \mathrm{M})$, values similar to cisplatin (3.9-4.7 $\mu \mathrm{M})$.

The interaction between complexes 1-4 and purine bases was evaluated employing guanosine (Gua) as a model system. Initially such interaction has been carried out directly in water media. However, complexes 1 $\mathbf{4}$ did not react with guanosine in this solvent. In addition, all attempts to remove coordinated halide/pseudohalide by using $\mathrm{AgNO}_{3}$ in water were unsuccessful. Aiming at generating more reactive and soluble complexes capable to readily interact with guanosine, we have employed the $\mathrm{AgNO}_{3} /$ dmf method [26] to afford in situ reactive and soluble solvento/nitrato $\mathrm{Pd}(\mathrm{II})$ complexes. The abstraction of anionic groups was performed by the addition of 2 equiv. of $\mathrm{AgNO}_{3}$ in dmf leading to the precipitation of silver halide and silver thiocyanate, then filtered through a Millipore filter. The resulting solution was combined with Gua (2.0 equiv.) and the guanosine binding was confirmed by ${ }^{1} \mathrm{H}$ NMR spectroscopy in $\left[\mathrm{D}_{4}\right] \mathrm{MeOD}$ (after solvent removal) and mass spectrometry (ESI $\dagger$ ). The observed

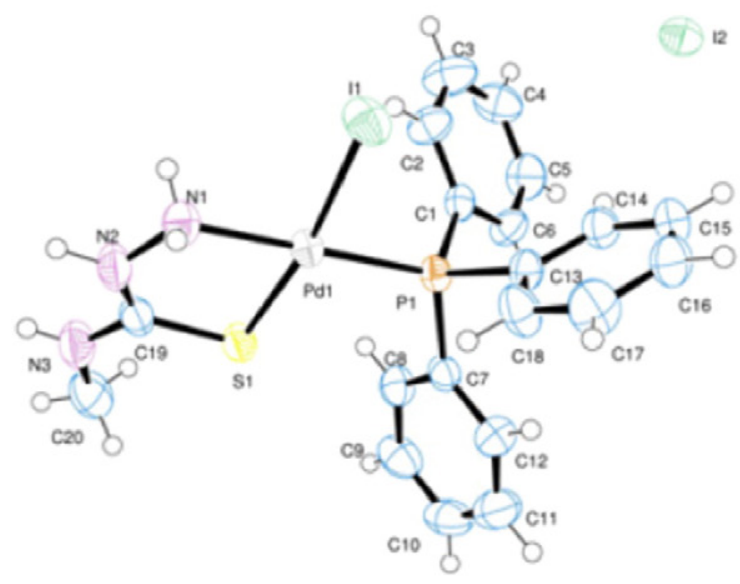

A

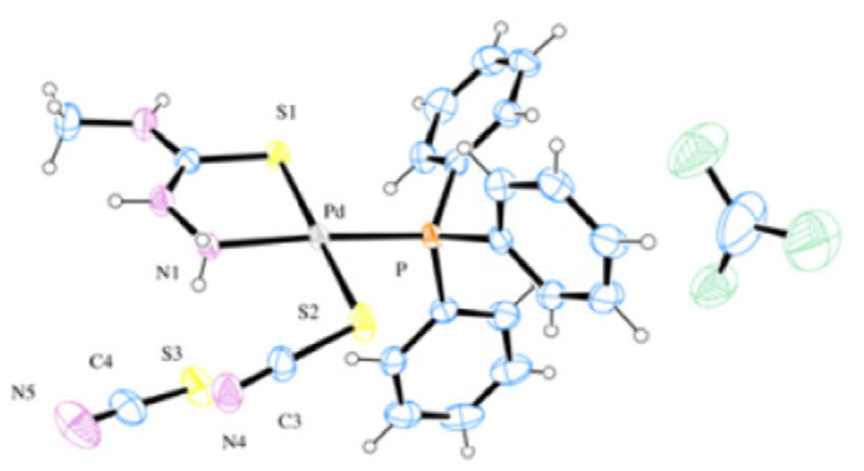

B

Fig. 1. Structures of $\mathbf{3}(\mathrm{A})$ and $\mathbf{4}(\mathrm{B})$. 
$\begin{array}{lllllllllll}\text { L1 } & \text { L2 } & \text { L3 } & \text { L4 } & \text { L5 } & \text { L6 } & \text { L7 } & \text { L8 } & \text { L9 } & \text { L10 } & \text { L11 }\end{array}$

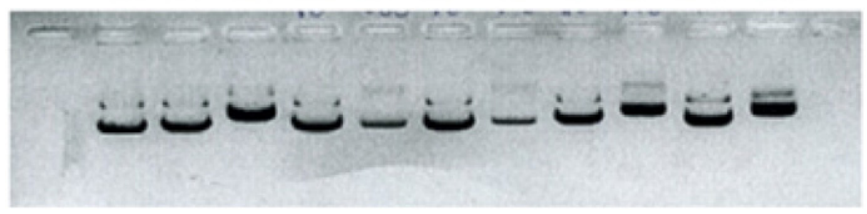

Fig. 2. Plasmid incubation with 1-4 and cisplatin after $24 \mathrm{~h}$. Line 1 : plasmid in water. Line 2: plasmid in water/dmf (2.5\%). Line 3: cisplatin $(20 \mu \mathrm{m})$. Line 4: $2(10 \mu \mathrm{m})$. Line 5: 2 $(100 \mu \mathrm{m})$. Line 6: $\mathbf{3}(10 \mu \mathrm{m})$. Line 7: $\mathbf{3}(100 \mu \mathrm{m})$. Line 8: $\mathbf{4}(10 \mu \mathrm{m})$. Line 9: $\mathbf{4}(100 \mu \mathrm{m})$. Line 10: $5(10 \mu \mathrm{m})$. Line 11: $\mathbf{5}(100 \mu \mathrm{m})$.

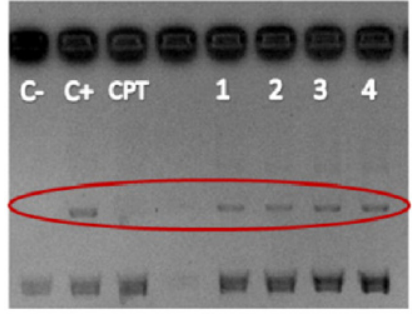

(A)



(B)
Fig. 3. Topoisomerase I relaxation assay with 1-8 and camptothecin (CPT) at $100 \mu \mathrm{M}$. C (supercoiled plasmid). C+ (supercoiled plasmid and topoisomerase). 1-4 (A) and 5-8 (B).

downfield shift of the ${ }^{1} \mathrm{H}$ NMR signal corresponding to guanosine $\mathrm{H} 8 \mathrm{nu}-$ cleus agrees well with the Gua coordination through N7 [27]. The mass spectra showed the expected molecular peak at $m / z=755$, corresponding to the monocharged adduct $\left[\mathrm{Pd}(\mathrm{Gua})(4-\mathrm{MeT})\left(\mathrm{PPh}_{3}\right)\right]^{+}$. This finding indicates that triphenylphosphine is maintained as the ligand and a proton is abstracted during guanosine coordination, probably through the acidic thiosemicarbazide proton.

The effect of 1-4 on the structure of a supercoiled DNA was evaluated by their ability to modify the mobility of the circular pNFkB-luc plasmid in a gel electrophoresis assay (Fig. 2).

All complexes were capable of changing electrophoretic mobility of circular DNA. Nevertheless, it has only occurred at high concentrations $(100 \mu \mathrm{M})$. These data suggested that the cytotoxicity mechanisms of the compounds 1-4 may be associated with additional molecular
Table 2

$\mathrm{IC}_{50}$ values for the cathepsin B inhibition of $\mathbf{3}$ and $\mathbf{7 .}$

\begin{tabular}{ll}
\hline Complex & $\mathrm{IC}_{50}(\mu \mathrm{M})$ \\
\hline$\left[\mathrm{PdI}(4-\mathrm{MeT})\left(\mathrm{PPh}_{3}\right)\right] \mathrm{I}(\mathbf{3})$ & $5.53 \pm 0.66$ \\
{$\left[\mathrm{PdI}(4-\mathrm{PhT})\left(\mathrm{PPh}_{3}\right)\right] \mathrm{I}(\mathbf{7})$} & $8.81 \pm 0.80$ \\
\hline
\end{tabular}

targets. However, it is important to emphasize that the scarce reactivity of these complexes towards plasmid DNA is not sufficient to rule out the involvement of DNA as a molecular target. To assess the mechanism of the cytotoxicity of $\mathbf{1 - 4}$, an in vitro study of the inhibitory effects of each complex on topo I and II was undertaken.

The inhibitory ability of complexes 1-4 on the activity of topo I (Fig. 3) and II $\alpha$ (Fig. 4) has been evaluated by incubating topo and circular plasmideal DNA pBR320 in a concentration-dependent manner [ESI†]. In addition, we have also investigated the inhibitory activity induced by analogous compounds of the type $\left[\mathrm{PdX}\left(\mathrm{PPh}_{3}\right)(4-\mathrm{PhT})\right] \mathrm{X}\{4-$ $\mathrm{PhT}=$ 4-phenyl-3-thiosemicarbazide; $\mathrm{X}=\mathrm{Cl}(\mathbf{5}), \operatorname{Br}(\mathbf{6}), \mathrm{I}(\mathbf{7}), \operatorname{SCN}(\mathbf{8})\}$ [21] aiming at evaluating the influence of substituent at $\mathrm{N}-3$ position of thiosemicarbazide ligand on the observed activity. With regard to DNA-topoisomerase I (topo I), gel shift assay results (Fig. 3) clearly showed that supercoiled pBR320 DNA was fully relaxed by the enzyme (Lane 1, topo I) while none of the Pd(II) compounds were able to inhibit the action of Topo I at $50 \mu \mathrm{M}$.

As shown in Fig. 4, with increasing the concentration of complexes $(5,25,50,100 \mu \mathrm{M})$, the levels of relaxed form were inhibited successively and finally the activity of topo II $\alpha$ was totally inhibited at $5 \mu \mathrm{M}$ (compounds 3, 6, 7 and 8), $25 \mu \mathrm{M}$ (1 and 4) or $50 \mu \mathrm{M}$ (2). Complex $\left[\mathrm{PdCl}\left(\mathrm{PPh}_{3}\right)(4-\mathrm{PhT})\right] \mathrm{Cl}(\mathbf{5})$ appeared unable to inhibit the enzyme at any tested concentration. The ability of compounds $\mathbf{3 , 6 , 7}$ and 8 to inhibit the relaxation of DNA was six fold more potent than etoposide (35 $\mu \mathrm{M})$, an usual anticancer drug [28].

At this point, it is very difficult to rationalize the observed inhibitory concentration ranges in terms of structure-activity relationship. As a whole, substitution of coordinated chlorido with more polarizable and bulkier anionic ligands, such as I, tend to increase the inhibitory effect. This finding implies that the strength of the $\mathrm{Pd}-\mathrm{X}$ bond and/or the kinetic differences between the coordinated anionic ligands play an important role in topo II inhibition. In addition, we assumed that the steric hindrance at $\mathrm{N}-3$ position of the thiosemicarbazide ligand may also affect the observed inhibitory effect since most of 4-phenyl-3-

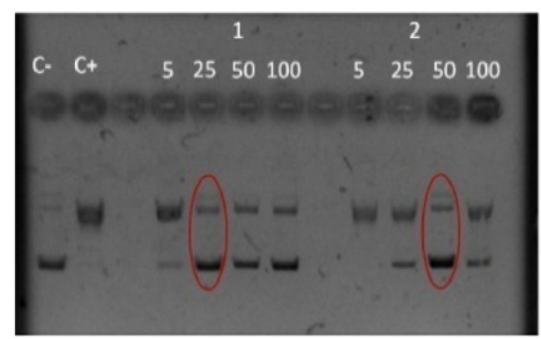

(A)

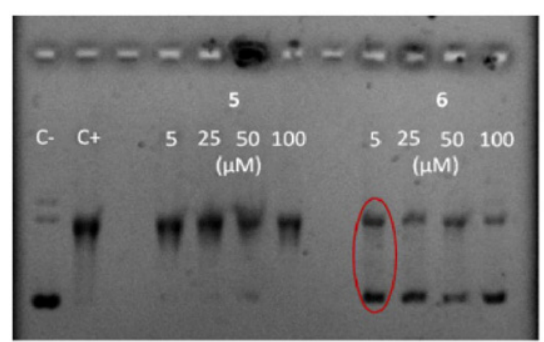

(C)

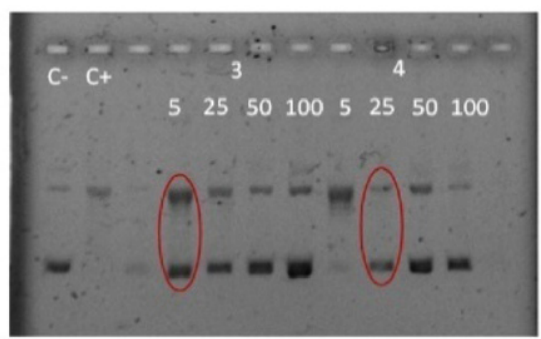

(B)

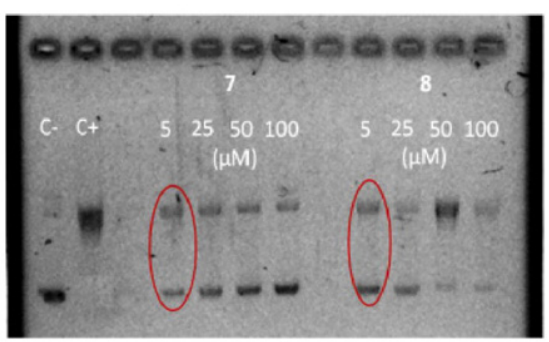

(D)

Fig. 4. Topoisomerase II relaxation assay. C - (supercoiled plasmid). C+ (supercoiled plasmid, topoisomerase and ATP). 1 and 2 (A). 3 and 4 (B). 5 and 6 (C). 7 and 8 (D). 
thiosemicarbazide derivatives ( 6,7 and $\mathbf{8})$ demonstrated to be more active than the majority of their 4-MeT analogues.

We have selected the iodo-complexes $\mathbf{3}$ and $\mathbf{7}$ to evaluate their ability to induce the inhibition of cathepsin B. It was determined through the inhibition of cathepsin B activity, which was measured spectrofluorometrically, based on the procedure using the fluorogenic substrate carbobenzoxy-Phe-Arg-7-amido-4-methylcoumarin(Z-PheArg-MCA) (Calbiochem, La Jolla, CA, USA). Fluorescence was measured in a Hitachi F-2500 spectrofluorometer at $\lambda_{\mathrm{ex}}=380 \mathrm{~nm}$ and $\lambda_{\mathrm{em}}=$ $460 \mathrm{~nm}$ [29]. Inhibitory activity of iodo-complexes 3 and 7 was determined by measuring the residual hydrolytic activity of cysteine peptidase after pre-incubation with different inhibitor concentrations. The inhibitory activity against the cysteine protease cathepsin B and the obtained $\mathrm{IC}_{50}$ values are listed in Table 2.

Both complexes inhibited the enzyme activity, exhibiting $\mathrm{IC}_{50}$ values inferior than $10 \mu \mathrm{M}$. The inactivation of cathepsin B by compounds 3 and 7 may be attributed to the high nucleophilic character of the thiolate group at the active site of cathepsin B combined with the high thiophilic character of the palladium atom [14]. A nucleophilic attack at the metal center by the thiolate followed by the displacement of the iodide ion or other leaving group coordinated to palladium is expected to be an important step in the interaction of these $\mathrm{Pd}(\mathrm{II})$ compounds and cathepsin B.

The molecular mechanism underlying the topo II inhibition effect of these palladium(II) compounds is unclear. However, taking into account that they were unable to inhibit topo I, whose action is independent of the ATP, we hypothesized that these complexes may act as catalytic inhibitors of topo II, competing with ATP for the ATPase domain [30]. On the other hand, the well-known ability of Pd compounds to interact with biological thiolato groups may also suggest the involvement of thiol modification in topo II cleavage complex formation [31]. Nevertheless, further studies are required in order to elucidate the mechanisms of action of these compounds.

\section{Acknowledgements}

We thank the São Paulo State University (UNESP), Institute of Chemistry of Araraquara. This work was sponsored by FAPESP 2013/20156-5, CNPq and CAPES.

\section{Appendix A. Supplementary data}

Supplementary data to this article can be found online at http://dx. doi.org/10.1016/j.jinorgbio.2016.02.039.

\section{References}

[1] K.D. Corbett, J.M. Berger, Annu. Rev. Biophys. Biomol. Struct. 33 (2004) 95-118.

[2] A.K. McClendon, N. Osheroff, Mutat. Res. 623 (2007) 83-97.

[3] J.M. Fortune, N. Osheroff, Prog. Nucleic Acid Res. Mol. Biol. 64 (2000) 221-253.

[4] T.K. Li, L.F. Liu, Annu. Rev. Pharmacol. Toxicol. 41 (2001) 53-77.

[5] G. Chen, D. Templeton, D.P. Suttle, D.W. Stacey, Oncogene 18 (1999) 7149-7160.

[6] A.K. Larsen, A.E. Escargueil, A. Skladanowski, Pharmacol. Ther. 99 (2003) 167-181.

[7] K.R. Hande, Update on Cancer Therapeutics, 32008 13-26.

[8] D.A. Burden, N. Osheroff, Biochim. Biophys. Acta 1400 (1998) 139-154.

[9] B.B. Hasinoff, X. Wu, A. Begleiter, L.J. Guziec, F. Guziec Jr., A. Giorgianni, S. Yang, Y Jiang, J.C. Yalowich, Cancer Chemother. Pharmacol. 57 (2006) 221-233.

[10] N. Zhou, H. Xiao, T.-K. Li, A. N.-E-Kamal, L.F. Liu, J. Biol. Chem. 278 (2003) 29532-29537.

[11] X. Wu, J.C. Yalowich, B.B. Hasinoff, J. Inorg. Biochem. 105 (2011) 833-838.

[12] X. Wu, H. Liang, K.A. O'Hara, J.C. Yalowich, B.B. Hasinoff, Chem. Res. Toxicol. 21 (2008) 483-493.

[13] B.B. Hasinoff, X. Wu, O.V. Krokhin, W. Ens, K.G. Standing, J.L. Nitiss, T. Sivaram, A Giorgianni, S. Yang, Y. Jiang, J.C. Yalowich, Mol. Pharmacol. 67 (2005) 937-947.

14] S. Kawanishi, A. Yokoyama, H. Tanaka, Chem. Pharm. Bull. 20 (1972) 262-268.

[15] D.P. Santana, P.A. Faria, E.J. Paredes-Gamero, A.C.F. Caires, I.L. Nantes, T. Rodrigues, Biochem. J. 417 (2009) 247-256.

[16] F.A. Serrano, A.L. Matsuo, P.T. Monteforte, A. Bechara, S.S. Smaili, D.P. Santana, T Rodrigues, F.V. Pereira, L.S. Silva, J. Machado Jr., E.L. Santos, J.B. Pesquero, R.M. Martins, L.R. Travassos, A.C.F. Caires, E.G. Rodrigues, BMC Cancer 11 (2011) 296-311.

[17] C. Bincoletto, I.L.S. Tersariol, C.R. Oliveira, S. Dreher, D.M. Fausto, M.A. Soufen, F.D. Nascimento, A.C.F. Caires, Bioorg. Med. Chem. 13 (2005) 3047-3055.

[18] R. Mosi, I.R. Baird, J. Cox, V. Anastassov, B. Cameron, R.T. Skerlj, S.P. Fricker, J. Med. Chem. 49 (2006) 5262-5272.

[19] J. Spencer, A. Casini, O. Zava, R.P. Rathnam, S.K. Velhanda, M. Pfeffer, S.K. Callear, M.B. Hursthouse, P.J. Dyson, Dalton Trans. (2009) 10731-10735.

[20] J. Chen, Y.-W. Huang, G. Liu, Z. Afrasiabi, E. Sinn, S. Padhye, Y. Ma, Toxicol. Appl Pharmacol. 197 (2004) 40-48.

[21] F.V. Rocha, C.V. Barra, A.E. Mauro, I.Z. Carlos, L. Nauton, M. El Ghozzi, A. Gautier, L Morel, A.V.G. Netto, Eur. J. Inorg. Chem. (2013) 4499-4505.

[22] C.V. Barra, F.V. Rocha, A. Gautier, L. Morel, M.B. Quilles, I.Z. Carlos, O. Treu-Filho R.C.G. Frem, A.E. Mauro, A.V.G. Netto, Polyhedron 65 (2013) 214-220.

[23] F.V. Rocha, C.V. Barra, A.V.G. Netto, A.E. Mauro, I.Z. Carlos, R.C.G. Frem, S.R. Ananias, M.B. Quilles, A. Stevanato, M.C. da Rocha, Eur. J. Med. Chem. 45 (2010) 1698-1702.

24] A.C. Moro, A.E. Mauro, A.V.G. Netto, S.R. Ananias, M.B. Quilles, I.Z. Carlos, F.R. Pavan, C.Q.F. Leite, M. Horner, Eur. J. Med. Chem. 44 (2009) 4611-4615.

[25] P. Kalaivani, R. Prabhakaran, E. Ramachandran, F. Dallemer, G. Paramaguru, R. Renganathan, P. Poornima, V. Vijaya Padma, K. Natarajan, Dalton Trans. 41 (2012) 2486-2499.

[26] L.S. Hollis, A.R. Amundsen, E.W. Stern, J. Med. Chem. 32 (1989) 128; G. Zhao, H. Lin, S. Zhu, H. Sun, Y. Chen, J. Inorg. Biochem. 70 (1998) 219-226.

[27] A. Chevry, M.-L. Teyssot, A. Maisonial, P. Lemoine, B. Viossat, M. Traïkia, D.J. Aitken, G. Alves, L. Morel, L. Nauton, A. Gautier, Eur. J. Inorg. Chem. (2010) 3513-3519.

[28] F. Gao, H. Chao, L.-N. Ji, Chem. Biodivers. 5 (2008) 1962-1979.

[29] A. Gianotti, C.A. Sommer, A.K. Carmona, F. Henrique-Silvia, Biol. Chem. 389 (2008) 447-453.

[30] H. Huang, Q. Chen, X. Ku, L. Meng, L. Lin, X. Wang, C. Zhu, Y. Wang, Z. Chen, M. Li, H. Jiang, K. Chen, J. Ding, H. Liu, J. Med. Chem. 53 (2010) 3048-3064.

[31] H. Wang, Y. Mao, A.Y. Chen, N. Zhou, E.J. LaVoie, L.F. Liu, Biochemistry 40 (2001) 3316-3323. 